\title{
Radiosensitizing potential of rutin against human colon adenocarcinoma HT-29 cells
}

\author{
Vijay $\mathrm{M}^{1}$, Sivagami $\mathrm{G}^{1}$, Thayalan $\mathrm{K}^{2}$, Nalini $\mathrm{N}^{1}$ \\ Department of Biochemistry and Biotechnology, Faculty of Science, Annamalai University, Annamalainagar, Tamilnadu, India. \\ nalininam@yahoo.com
}

\begin{abstract}
AIM: The present study was focused at evaluating the potential of rutin to improve the radiotherapeutic index and thereby the cytotoxicity towards colon cancer cells.

MATERIALS AND METHODS: HT-29 cells were pre-treated with rutin and the effect on cell proliferation was determined by MTT assay followed by exposure to radiation. After irradiation, experimental groups were sham control, rutin alone, radiation alone, rutin along with radiation-treated HT-29 cells.

RESULTS: Cytotoxicity study illustrated that treatment of HT-29 cells with different concentrations of rutin reduced cell proliferation in a dose- and time-dependent manner. After irradiation, the HT-29 cells revealed that the combined effect of $4 \mathrm{~Gy}$ radiation and rutin at $80 \mu \mathrm{M}$ concentration showed a decrease in cell viability as compared to rutin-alone treated and $4 \mathrm{~Gy}$-alone irradiated HT-29 cells. Furthermore, the increase in apoptotic cells, change from normal nuclei to abnormal nuclei, alterations in mitochondrial membrane potential, increase in DNA damage, increase in levels of lipid peroxidative markers, and decrease in antioxidant status were observed in $4 \mathrm{~Gy}$ - and rutin-treated group as compared to the other treated groups.

CONCLUSIONS: Combined effect of rutin and radiation in HT-29 cells leads to a more pronounced cell death rate. Thus, rutin exhibits radiosensitizing effects on HT-29 cells (Tab. 4, Fig. 8, Ref. 42). Text in PDF www.elis.sk. KEY WORDS: radiosensitization, rutin, apoptosis, DNA damage, prooxidant.
\end{abstract}

\section{Introduction}

Colorectal cancer (CRC) is one of the leading causes of cancer lethality. The frequency of colon cancer varies around the world. Worldwide it accounts for approximately 1 million new cancers and 1.5 million deaths, equating with $10 \%$ of all cancer deaths annually (1). Cell lines derived from tumours and tissues comprise the most frequently used living systems in modern biomedical research. HT29 cell line is a colon cancer cell line, tumourigenic in nature, isolated from the tumour of a 44-year-old Caucasian woman with colon adenocarcinoma. All cancer cells hold mutation in combinations of tumour suppressors and oncogenes. Mutation in p53 gene is one of the most common genetic changes in cancer cells. Such cancer cells can implement various mechanisms to overrule apoptosis (2).

Apoptosis is a significant mode of cell death subsequent to treatment with cytotoxic drugs or radiation in a variety of tumour

${ }^{1}$ Department of Biochemistry and Biotechnology, Faculty of Science, Annamalai University, Annamalainagar, Tamilnadu, India, and ${ }^{2}$ Medical Physics Division, Dr. Kamakshi Memorial Hospital, No: 1, Radial Road, Pallikaranai, Chennai, Tamil Nadu, India

Address for correspondence: Dr. N. Nalini, Department of Biochemistry and Biotechnology, Annamalai University, Annamalainagar-608002, Tamilnadu, India.

Phoe: +91.4144.239141, Fax: +91.4144.238343

Acknowledgement: The authors gratefully acknowledge Dr. Kamakshi Memorial hospital, Chennai, Tamil Nadu, India for providing the radiation facilities necessary to carry out our research work. types and may possibly play a considerable role in drug and radiation enhancement (3). Mitochondrial membrane potential $(\Delta \Psi \mathrm{m})$ is the main factor that determines cell survival and apoptosis. $\Delta \Psi \mathrm{m}$ is critical for maintaining the physiological function of the respiratory chain to generate ATP. A significant loss of $\Delta \Psi \mathrm{m}$ depletes cellular energy which subsequently leads to their death. Reactive oxygen species (ROS) are important signalling molecules, but their accumulation in pathological conditions leads to oxidative stress. ROS can cause DNA damage (4), and reactive nitrogen species (RNS) such as peroxynitrite also cause DNA damage. An excess in ROS production can deregulate the equilibrium and cause lipid peroxidation and protein oxidation. To prevent oxidative stress, neutralization of excessive ROS is accomplished by antioxidant enzymes to detoxify free radicals. Depending on the factors such as metal-reducing potential, $\mathrm{pH}$, solubility characteristics, and chelating behaviour, the plant-derived antioxidant polyphenols can possess both prooxidative and antioxidative properties (5).

Rutin is one of the flavonoids abundant in many plants, fruits, and vegetables. The richest source of rutin is buckwheat, citrus fruits (orange, grapefruit, lemon, lime) and berries (mulberry, ash tree fruits, and cranberries). It comprises many pharmacological properties like anticarcinogenic (6), antiinflammatory (7), antiproliferative (8), antihypercholesterolemic (9), cytoprotective, vasoprotective, hepatoprotective (10) and neuroprotective (11) effects. Rutin can scavenge free radicals and inhibit superoxide radical production, as well as enhance the activities of antioxidant enzymes (12). 


\section{1-178}

Cancer treatment involving radiotherapy and usage of high doses of therapeutic agents might sometimes lead to non-particular toxicities and even create radiation resistance and drug resistance. To enhance the therapeutic index of radiotherapy, the research is focused on chemotherapeutic agents to increase the efficacy of radiotherapy (13). Such ideal strategy of combining anticancer agents with radiation preferentially leads to more cell deaths when compared to individual radiotherapy and chemotherapy regimens. Radiosensitization is a technique which involves the combination of chemotherapeutic agents and irradiation that are capable of killing cancer cells without affecting the normal cells. A number of chemotherapeutic agents possessing radiosensitizing potential are shown to be effective against many cancer cells. Radiosensitizing agents can enhance sensitivity of cancer cells (14). To be clinically efficient, a radiosensitizing agent should possess the capacity to affect the tumour cells but not the normal cells (15). Nowadays this mode of therapy has been improving the efficiency of cancer treatment, and thereby decreasing the side effects. Thus our present study is intended to investigate the effect of rutin, a potential chemotherapeutic agent in combination with radiation on the proliferation of HT-29 colon cancer cells.

\section{Materials and methods}

\section{Chemicals}

3-(4,5-dimethyl thiazol-2yl)-2, 5-diphenyl tetrazolium bromide (MTT), trypsin EDTA, phenazinemethosulphate (PMS), nitrobluetetrazolium (NBT), 5,5-dithiobis 2-nitro benzoic acid (DTNB), reduced glutathione (GSH), reduced nicotinamide adenine dinucleotide (NADH), reduced nicotinamide adenine dinucleotide phosphate (NADPH), low melting agarose and normal melting agarose were obtained from Himedia Lab Limited, Mumbai. Rutin, ethidium bromide (EtBr), rhodamine 123 and Hoechst 33258 were obtained from Sigma Aldrich Chemicals Co, USA. All other chemicals utilized in our study were of analytical grade and obtained from SD Fine Chemicals Limited, India.

\section{Culture medium}

RPMI 1640 medium with glutamine and without sodium bicarbonate was obtained from Sigma Aldrich Chemicals Co, USA.

\section{Cancer cell lines}

The colon cancer cell line (HT-29) used in the present study was procured from National Centre for Cell Science (NCCS), Pune, India.

\section{Maintenance of cells}

HT-29 cells were grown as a monolayer in RPMI 1640 medium with $10 \%$ FBS and $2 \%$ antibiotics. Stock cultures were sub-cultured every 7 th day after harvesting the cells with trypsin EDTA and then seeding them in tissue culture flask to maintain the exponential phase.

\section{Rutin preparation}

Cultured HT-29 cells were treated with different concentrations of rutin ranging from $10-100 \mu \mathrm{M}$ dissolved in $0.5 \%$ dimethyl sulphoxide (DMSO) for $24 \mathrm{~h}$ while for each concentration six replicates were processed $(n=6)$.

\section{Cytotoxicity assay}

The $50 \%$ inhibitory concentration of rutin was determined by MTT assay (16). HT-29 cells were grown in 96-well microtitre plate $\left(5 \times 10^{3}\right.$ cells $/$ well $)$ for $24 \mathrm{~h}$ after seeding. The plates were incubated with rutin at different concentrations $(10 \mu \mathrm{M}$ to $100 \mu \mathrm{M})$ for $24 \mathrm{~h}, 48 \mathrm{~h}$, and $72 \mathrm{~h}$, respectively (tetraplicates for each concentration). The medium was refreshed and $20 \mu \mathrm{l}$ of MTT solution $(5 \mathrm{mg} / \mathrm{ml})$ was added. Then plates were incubated for $3 \mathrm{~h}$ in the dark. The developed formazan crystals were solubilized in $100 \mu \mathrm{l}$ of DMSO. The developed colour was measured using an ELISA reader (Bio Rad, USA) at wavelength of $570 \mathrm{~nm}$ with reference wavelength of $630 \mathrm{~nm}$. MTT results were analyzed by graphical method, such that the graph of absorbance against the concentration of rutin was plotted and $\mathrm{IC}_{50}$ concentration was determined. To normalize the series of curves, the data were then converted to percentage inhibition curve.

\section{Irradiation protocol}

HT-29 cells from each group were grown in $\mathrm{T}_{75}$ tissue culture flask and then exposed to a dose of 4 Gray (Gy) radiation (17) at Dr. Kamakshi Memorial Hospital, Chennai, India.

\section{Experimental groups}

To elucidate the radiosensitizing effects of rutin, HT-29 cells were treated with rutin $(80 \mu \mathrm{M})$ for $24 \mathrm{~h}$ and then post-irradiated with 4 Gy of X-ray radiation. The following were the experimental groups, which are represented as

Group 1: Sham control,

Group 2: Rutin-treated $(80 \mu \mathrm{M})$,

Group 3: irradiated (4 Gy)

Group 4: Rutin-treated $(80 \mu \mathrm{M})+$ irradiated (4 Gy) HT-29 cancer cells.

\section{Cell morphology assessment}

Cellular morphology induced by treatment of HT-29 cells with rutin and $4 \mathrm{~Gy}$ radiation was determined on staining with acridine orange and ethidium bromide $(\mathrm{AO} / \mathrm{EtBr})$ by the method of Spector et al (18). HT-29 cells were grown in 6 -well plates $\left(5 \times 10^{3}\right.$ cells/well $)$ for $24 \mathrm{~h}$. The cells were then incubated with $\mathrm{IC}_{50}$ dose of rutin and 4 Gy radiation for $24 \mathrm{~h}$. After incubation, the cells were washed with phosphate-buffered saline. Then the cells were subjected to trypsinization and stained with $\mathrm{AO} / \mathrm{EtBr}$ and viewed under a fluorescent microscope (Carl Zeiss, Jena, Germany) with excitation wavelength of $502 \mathrm{~nm}$ and emission wavelength of $526 \mathrm{~nm}$. The number of cells revealing characteristics of live cells, apoptosis, and necrosis were counted manually.

\section{Nuclear morphology assessment}

Nuclear morphology was assessed to identify the nature of HT-29 cells changing from normal nuclei to abnormal nuclei. HT-29 cells were grown in 6 -well plates $\left(5 \times 10^{3}\right.$ cells/well) for 24 h. The cells were then incubated with the $\mathrm{IC}_{50}$ dose of rutin and 
exposed to $4 \mathrm{~Gy}$ radiation for $24 \mathrm{~h}$. After incubation, the cells were washed with phosphate-buffered saline. The cells were then trypsinized and placed on a glass slide, stained with Hoechst 33258, and viewed under a fluorescent microscope (Carl Zeiss, Jena, Germany) with excitation wavelength of $350 \mathrm{~nm}$ and emission wavelength of $460 \mathrm{~nm}$.

Measurement of mitochondrial transmembrane potential ( $\Delta \Psi m)$

HT-29 cells placed in 6-well plates were treated for $24 \mathrm{~h}$ with $\mathrm{IC}_{50}$ concentration of rutin and $4 \mathrm{~Gy}$ radiation. The cells were stained with Rhodamine 123 dye after 12-h exposure. The mitochondrial depolarization patterns of the cells were observed under a fluorescent microscope (Carl Zeiss, Jena, Germany) fitted with a $377-355 \mathrm{~nm}$ filter at $400 \mathrm{X}$ magnification, and the number of cells showing dark green fluorescence and diminished green fluorescence were counted.

\section{Estimation of DNA damage}

DNA damage was estimated by alkaline single-cell gel electrophoresis (comet assay) according to the method of Singh et al (19). A volume of $200 \mu \mathrm{l}$ of $1 \%$ normal agarose in PBS at $65^{\circ} \mathrm{C}$ was layered gently on to a fully frosted microscopic slide, covered with cover slip, and placed over a frozen ice pack for about $5 \mathrm{~min}$. The cover slip was removed after the gel had been set. The cell suspension from one fraction to be analyzed was mixed with $1 \%$ low melting agarose at $37{ }^{\circ} \mathrm{C}$ in $1: 3$ ratio. A volume of 100 $\mu \mathrm{l}$ of this mixture was applied on top of the gel, coated over the slide, and allowed to set. A third coating with $100 \mu \mathrm{l}$ of $1 \%$ low melting agarose was applied on the gel containing the cell suspension and was allowed to set. After solidification of the agarose, the cover slips were removed and the slides were immersed in ice-cold lysis solution and placed in a refrigerator at $4{ }^{\circ} \mathrm{C}$ for $16 \mathrm{~h}$. After removing slides from lysis solution, the slides were allowed to stand in the electrophoresis buffer for about $20 \mathrm{~min}$, after which electrophoresis was carried out for $15 \mathrm{~min}$. After electrophoresis, the slides were removed, washed thrice in the neutralization buffer, and gently dabbed dry. A few drops of the working solution of EtBr were added on to the gel and the slide was covered with a cover slip. The stained DNA in the cells was examined using a fluorescent microscope.

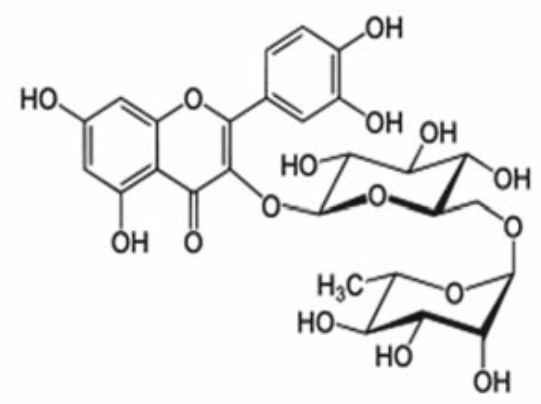

Fig. 1. Chemical structure of rutin $\left(\mathrm{C}_{27} \mathrm{H}_{30} \mathrm{O}_{16}\right)$.
Tab. $1.50 \%$ inhibitory concentration of rutin on HT-29 cells.

\begin{tabular}{lccc}
\hline HT-29 cells $\left(\mathrm{IC}_{50}\right)$ & $24 \mathrm{~h}$ & $48 \mathrm{~h}$ & $72 \mathrm{~h}$ \\
\hline Rutin $(\mu \mathrm{M})$ & $80.31 \pm 3.45$ & $64.87 \pm 5.41$ & $52.95 \pm 4.57$ \\
\hline
\end{tabular}

Data are presented as means \pm SD of six sets of experiment in each group. Values not sharing a common superscript letter $\left.{ }^{\left({ }^{a-e}\right.}\right)$ differ significantly at $\mathrm{p}<0.05$ (DMRT).

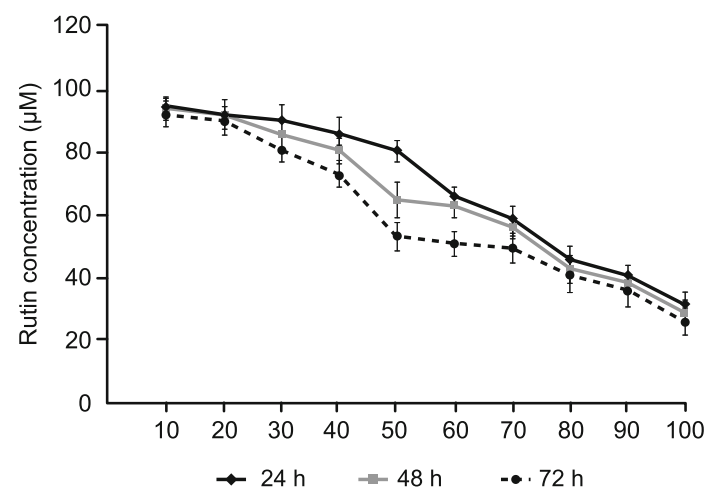

Fig. 2. Effect of rutin on the proliferation of HT-29 cells evaluated by MTT assay. Different concentrations of rutin $(10-100 \mu \mathrm{M})$ were used and studied at $24 \mathrm{~h}, 48 \mathrm{~h}$, and $72 \mathrm{~h}$. The $\mathrm{IC}_{50}$ value of rutin inhibits the proliferation of HT-29 cells in a time-dependent manner.
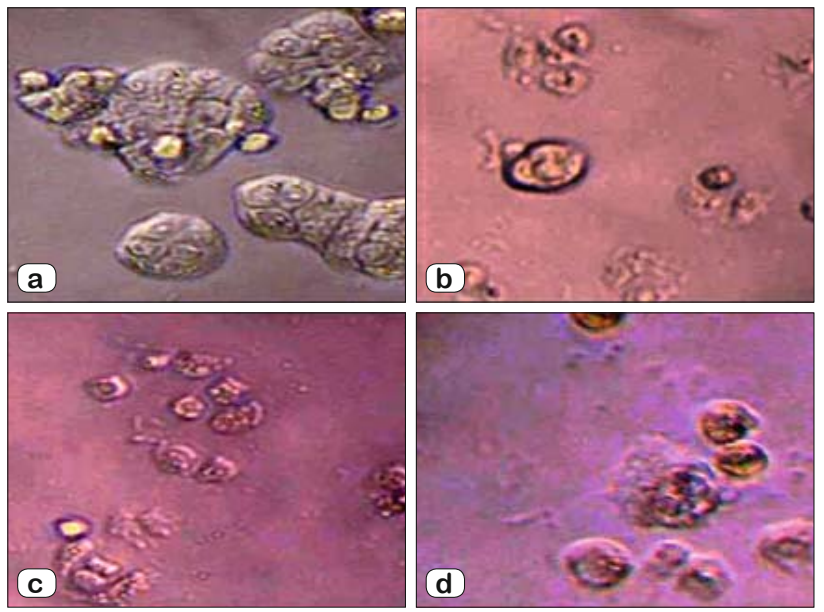

Fig. 3. Morphological changes in HT-29 cells after rutin-alone, and radiation-alone treatments and in combination (light microscopy); (a) sham control cells, (b) cells treated with rutin $(80 \mu \mathrm{M})$, (c) cells treated with $4 \mathrm{~Gy}$ radiation, (d) cells treated with both rutin and 4 Gy radiation.

\section{Assessment of lipid peroxidation}

HT-29 cells were seeded in a $\mathrm{T}_{75}$ flask. After reaching $90 \%$ confluence, cells were treated with $\mathrm{IC}_{50}$ concentration of rutin for $24 \mathrm{~h}$ and $4 \mathrm{~Gy}$ radiation at a dose of $1.6 \mathrm{~Gy} / \mathrm{min}$. The cells were harvested by trypsinization and washed with PBS. The cells were suspended in $130 \mathrm{mM} \mathrm{KCl}$ plus $50 \mathrm{mM}$ PBS containing $10 \mu \mathrm{M}$ dithiothreitol and centrifuged at $20,000 \times \mathrm{g}$ for $15 \mathrm{~min}\left(4^{\circ} \mathrm{C}\right)$. The supernatant was collected and used for biochemical estimations. The concentration of TBARS in the cell lysate was determined by the method of Niehaus and Samuelson (20). Similarly, the concentration of PCC in the cell lysate was also analyzed by the method of Levine et al (21). 


\section{1-178}

\section{Assessment of antioxidant status}

The activity of superoxide dismutase (SOD; EC 1.15.1.1) in the cell lysate was determined by the method of Kakkar et al (22), the activity of catalase (CAT; EC 1.11.1.6) by the method of Sinha (23), and the activity of glutathione peroxidase (GPx; EC 1.11.1.9) by the method of Rotruck et al (24), respectively.

\section{Statistical analysis}

All the data obtained were analysed by one-way analysis of variance (ANOVA) followed by Duncan's multiple range test (DMRT) using a commercially available statistics software package (SPSS for windows, version 17.0, Chicago, USA). Results were presented as means $\pm \mathrm{SD} ; \mathrm{p}<0.05$ were regarded as statistically significant.

\section{Results}

\section{Effect of rutin and radiation on cell cytotoxicity}

The cytotoxic effects of rutin were examined on cultured HT29 cells by exposing the cells to concentrations ranging from 10 $100 \mu \mathrm{M}$ for $24 \mathrm{~h}, 48 \mathrm{~h}$, and $72 \mathrm{~h}$. The reduced formazon was dissolved in DMSO and the absorbance was read in a 96-well plate microtitre reader. The graphs were plotted as percentage inhibition against the concentration of the test compound. The $\mathrm{IC}_{50}$ value of rutin on HT-29 cells is shown in Table 1 and Figure 2. Rutin induces cell death in a dose- and duration-dependent manner. Morphological changes in HT-29 cells treated and untreated with rutin and 4-Gy radiation are shown in Figure 3.

\section{Effect of rutin and radiation on cell morphology}

Cells treated with $\mathrm{IC}_{50}$ concentration of rutin for $24 \mathrm{~h}$ and exposed to $4 \mathrm{~Gy}$ radiation were stained with $\mathrm{AO} / \mathrm{EtBr}$. $\mathrm{AO} / \mathrm{EtBr}$ staining of cells treated with both rutin and $4 \mathrm{~Gy}$ radiation showed a higher percentage of cell death, whereas $\mathrm{AO} / \mathrm{EtBr}$ staining of cells
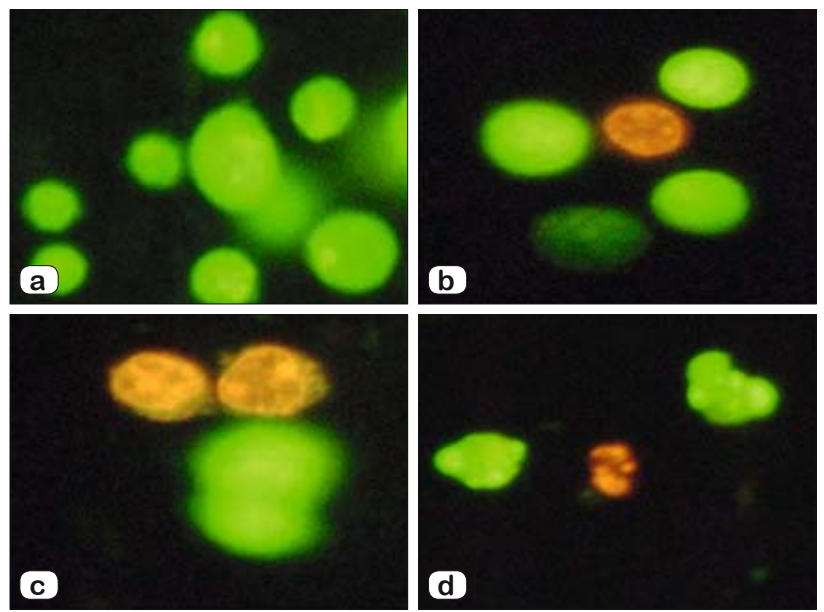

Fig. 4a. Effect of rutin-alone and radiation-alone treatments or in combination on HT-29 cells (AO/EtBr dual staining); (a) sham control cells, (b) cells treated with rutin $(80 \mu \mathrm{M})$, (c) cells treated with $4 \mathrm{~Gy}$ radiation, (d) cells treated with both rutin and $4 \mathrm{~Gy}$ radiation. treated with rutin alone and 4 Gy radiation alone showed a lower percentage of cell death (Fig. 4a). Quantitative data revealed that rutin alone at $80 \mu \mathrm{M}$ concentration exhibits death in $30 \%$ of cells, whereas on treatment with 4 Gy radiation alone the cell death occurred in $50 \%$ of cells and on treatment with rutin $(80 \mu \mathrm{M})$ along with 4 Gy radiation, the cell death occurred in $70 \%$ of cells with larger number of apoptotic bodies (Fig. 4b).

\section{Effect of rutin and radiation on nuclear morphology}

Hoechst 33258 staining of cells treated with rutin and 4 Gy radiation revealed more cells with abnormal nuclear morphology such as chromatin condensation and nuclear fragmentation. Hoechst 33258 staining showed that the HT-29 cells on treatment with both rutin $(80 \mu \mathrm{M})$ and 4 Gy radiation exhibited $80 \%$ of abnormal cells, whereas after the treatment with rutin alone (80 $\mu \mathrm{M})$ and 4 Gy radiation alone , the HT-29 cells showed the conversion of normal nuclei into abnormal nuclei in $40 \%$ and $55 \%$, respectively. The differences between the treated and untreated HT-29 cells were viewed under a fluorescent microscope and the representative photomicrographs and graphical representations are given in Figs $5 \mathrm{a}$ and 5b, respectively.

\section{Effect of rutin and radiation on mitochondrial membrane po- tential}

HT-29 sham control cells showed intense green fluorescence due to high mitochondrial transmembrane potential whereas cells treated with both rutin and 4-Gy radiation stained with rhodamine 123 showed a progressive loss of green fluorescence at $12 \mathrm{~h}$ and highly diminished fluorescence at $12 \mathrm{~h}$ due to a mild and complete loss of mitochondrial transmembrane potential, respectively. The differences between the untreated and treated cells were viewed under a fluorescent microscope and the representative photomicrographs and graphical representations are shown in Figures 6a and $6 \mathrm{~b}$.

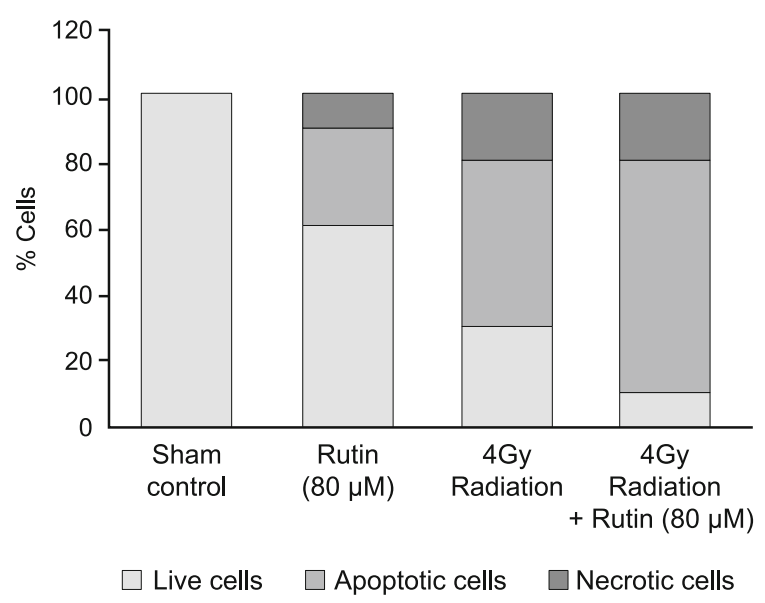

Fig. 4b. Quantitative data on the effect of rutin-alone and radiation-alone treatments alone or in combination on HT-29 cells reveal apoptosis and necrosis on staining with $\mathrm{AO} / \mathrm{EtBr}$. 

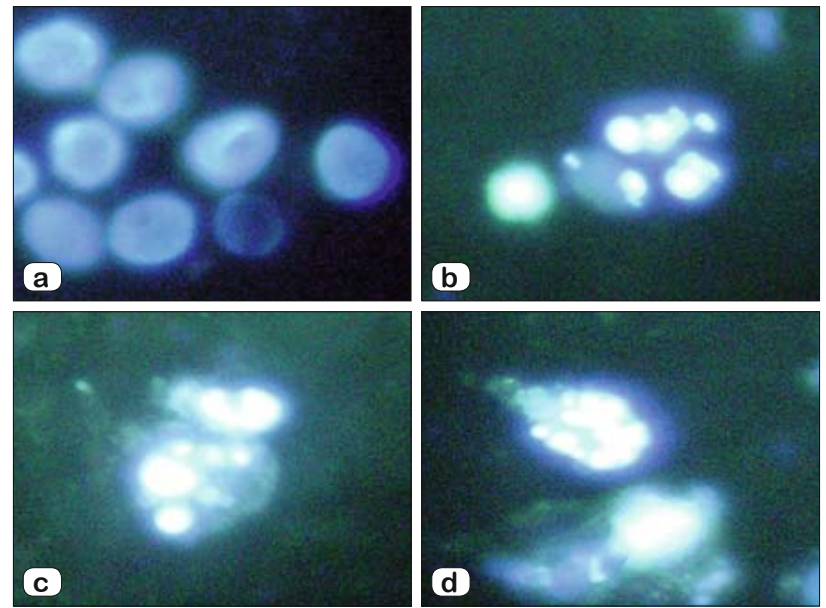

Fig. 5a. Effect of rutin-alone and radiation-alone treatments or in combination on nuclear morphology of HT-29 cells (Hoechst 33258 staining); (a) sham control cells, (b) cells treated with rutin $(80 \mu \mathrm{M})$, (c) cells treated with $4 \mathrm{~Gy}$ radiation, (d) cells treated with both rutin and $4 \mathrm{~Gy}$ radiation.
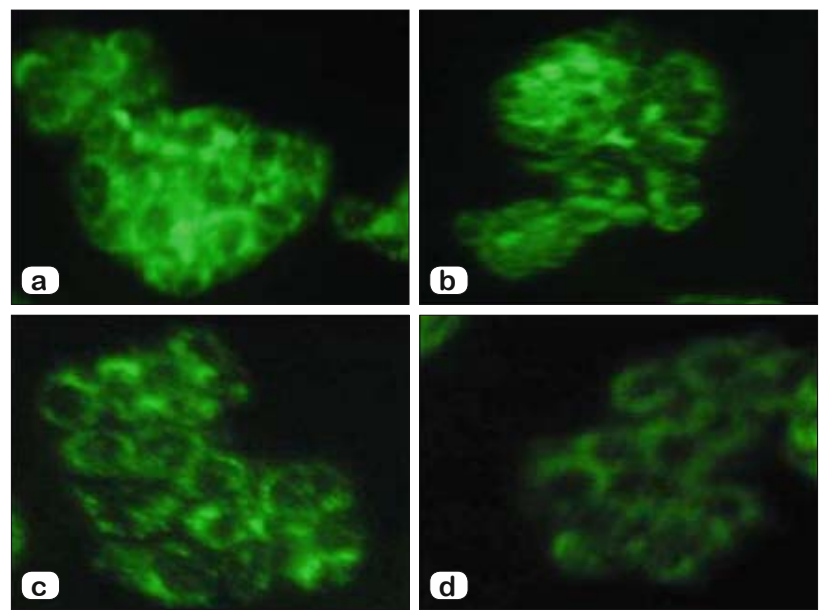

Fig. 6a. Effect of rutin-alone and radiation-alone treatments or in combination on mitochondrial transmembrane potential of HT-29 cells; (a) sham control cells, (b) cells treated with rutin $(80 \mu \mathrm{M})$, (c) cells treated with 4 Gy radiation, (d) shows cells treated with both rutin and $4 \mathrm{~Gy}$ radiation.

\section{Effect of rutin and radiation on DNA damage}

Treatment with both rutin and 4 Gy radiation caused severe DNA damage at $24 \mathrm{~h}$ (comet assay), whereas the cells treated with rutin alone and 4 Gy radiation alone exhibited lower percentage of DNA damage, as evidenced by the appearance of a prominent comet with a tail. The differences between rutin-alone treatment, radiation-alone treatment and the combined effect of both rutin and 4 Gy radiation were viewed under a fluorescent microscope and the representative photomicrographs and graphical representations are given in Figures $7 \mathrm{a}$ and $7 \mathrm{~b}$.

\section{Effect of rutin and radiation on TBARS and PCC}

Figures $8 \mathrm{a}$ and $8 \mathrm{~b}$ show the effect of rutin and 4 Gy radiation on TBARS and PCC in HT-29 cells. The levels of TBARS and

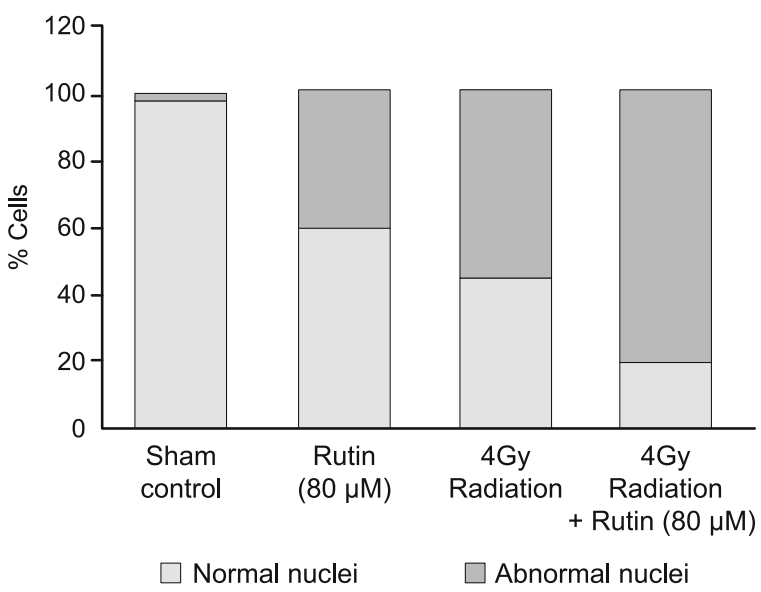

Fig. 5b. Quantitative data on the effect of rutin-alone and radiation-alone treatments or in combination on HT-29 cells reveal apoptosis on staining with Hoechst 33258.

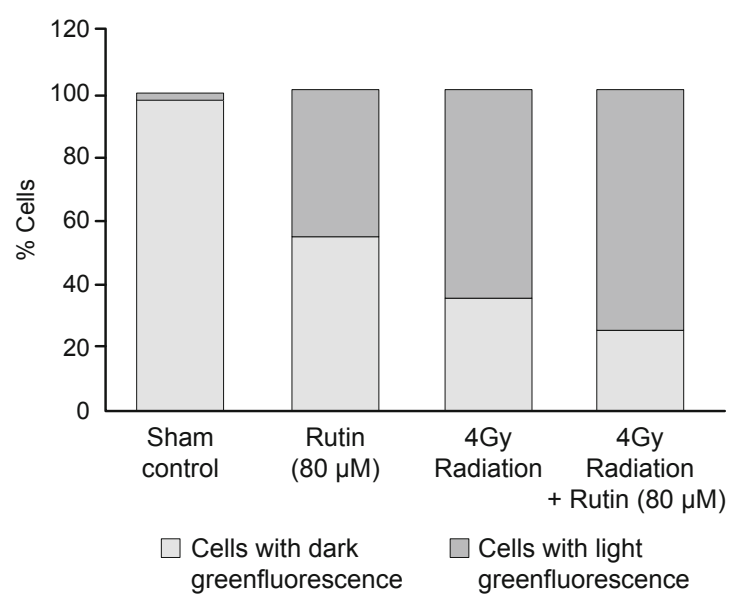

Fig. 6b. Quantitative data on the effect of rutin-alone and radiation-alone treatments or in combination on mitochondrial transmembrane potential in HT-29 cells.

PCC were low in sham control HT-29 cells. Upon treatment with both rutin and $4 \mathrm{~Gy}$ radiation, the levels of TBARS and PCC were significantly increased as compared to those in the cells treated with rutin alone, 4 Gy radiation alone and untreated HT-29 cancer cells. Moreover the combined effect of rutin and 4 Gy radiation on lipid peroxidation was significantly more pronounced.

\section{Effect of rutin and radiation on enzymatic antioxidants}

Tab 2, 3 and 4 show the effects of rutin and 4 Gy radiation on the activities of SOD, CAT and GPx in HT-29 cells. The results obtained demonstrate that the treatment of HT-29 cells for $24 \mathrm{~h}$ with both rutin and 4 Gy radiation significantly lowered the levels of enzymatic antioxidants, as compared to results obtained by treatment with rutin alone, radiation alone and from untreated HT-29 cells. 


\section{1-178}
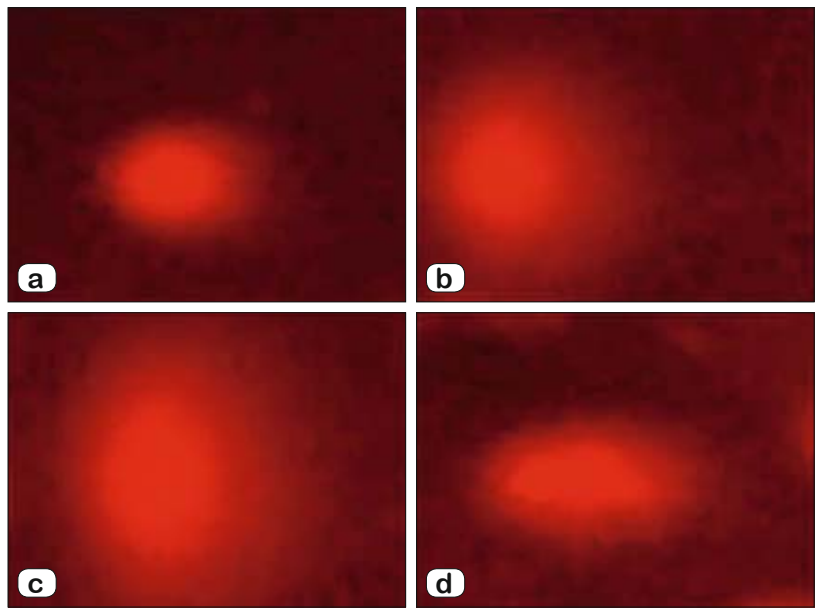

Fig. 7a. Effect of rutin-alone and radiation-alone treatments or in combination on DNA damage of HT-29 cell lines; (a) sham control cells, (b) cells treated with rutin $(80 \mu \mathrm{M})$, (c) cells treated with $4 \mathrm{~Gy}$ radiation, (d) cells treated with both rutin and $4 \mathrm{~Gy}$ radiation.

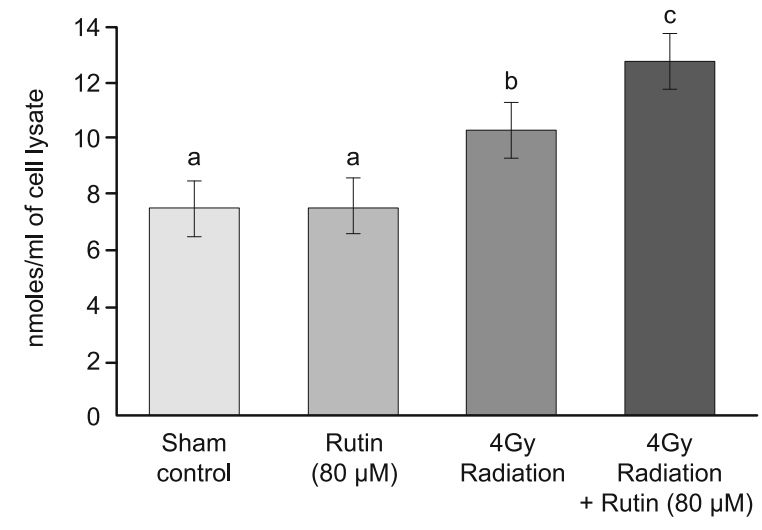

HT-29 cells

Fig. 8a. Effect of rutin and radiation on TBARS in the HT-29 cancer cells. Values are given as means \pm S.D. for six experiments in each group. Values not sharing a common marking $(a, b, c)$ differ significantly at $p<0.05$ (DMRT).

\section{Discussion}

Flavonoids are polyphenolic secondary metabolites of natural origin and polyphenols are known to increase irradiation consequences (25). Rutin, a flavonoid, is known to act against cancer cells and reduce their proliferation by virtue of its prooxidant and antioxidant effects (26). In recent years, colon cancer treatment involves therapies which have been stretched out gradually. To improve colon cancer therapeutic efficacy, chemotherapy and radiotherapy are combined.

Apoptosis, the mode of programmed cell death is characterized by many morphological changes such as membrane blebbing, nuclear DNA fragmentation, and phosphatidylserine (PS) translocation across the plasma membrane (27). ROS generation involves the activation of several signalling pathways leading

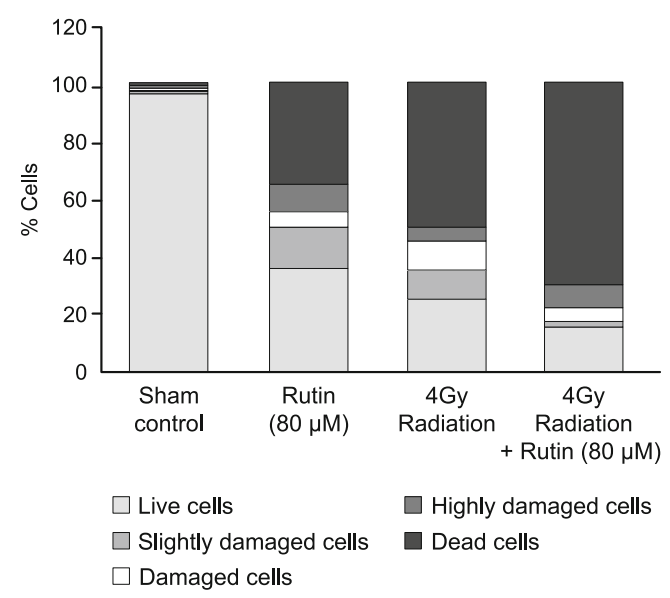

Fig. 7b. Quantitative data on the effect of rutin-alone and radiation-alone treatments or in combination on DNA damage in HT-29 cell lines.

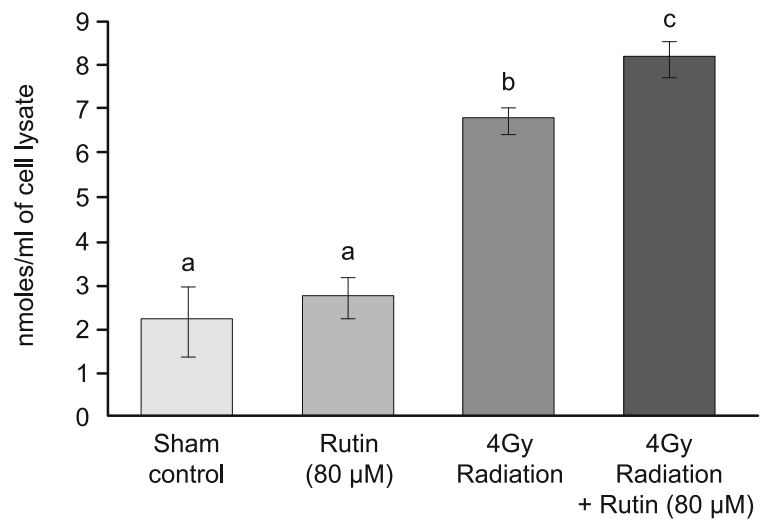

HT-29 cells

Fig. 8b. Effect of rutin and radiation on PCC in the HT-29 cancer cells. Values are given as means \pm S.D. for six experiments in each group. Values not sharing a common marking $(a, b, c)$ differ significantly at $\mathbf{p}<0.05$ (DMRT).

to the induction of apoptosis, activation of transcription factors, mitogenesis and gene expression (28). Radiation-induced apoptosis is known to play a significant role in determining cellular radiosensitivity (29). In the present study, dual staining of HT-29 cells subjected to combined treatment with rutin and radiation revealed a larger number of apoptotic bodies, larger rate of cell pyknosis, chromosomal condensation and nuclear fragmentation as compared to those in sham control, rutin-alone and radiation-alone treatment groups. Consistent with the above results, Hoechst staining of HT-29 cells for nuclear morphology revealed faint blue colour with irregularly shaped cells on treatment with both rutin and 4 Gy radiation. The above data suggest the marked cytotoxicity of the combination therapy (rutin and radiation) as compared to rutin-alone and radiation-alone treatments of HT-29 cell lines. In this context, our study has already 
Tab. 2. Effect of rutin and radiation on SOD in HT-29 cells ( $24 \mathrm{~h})$.

\begin{tabular}{lc}
\hline Groups & $\begin{array}{c}\text { SOD }(50 \% \text { inhibition of NBT } \\
\text { reduction } / \mathrm{min} / \mathrm{mg} \text { protein })\end{array}$ \\
\hline Sham Control & $22.54 \pm 1.51^{\mathrm{a}}$ \\
Rutin $(80 \mu \mathrm{M})$ & $23.97 \pm 1.25^{\mathrm{a}}$ \\
4 Gy radiation & $17.89 \pm 1.03^{\mathrm{b}}$ \\
4 Gy radiation + Rutin $(80 \mu \mathrm{M})$ & $15.15 \pm 1.32^{\mathrm{c}}$ \\
\hline Data are presented as means $\pm \mathrm{SD}$ of six sets of experiment in each group. Values \\
not sharing a common superscript letter $\left({ }^{\mathrm{a}-\mathrm{e}}\right)$ differ significantly at $\mathrm{p}<0.05$ (DMRT).
\end{tabular}

Tab. 3. Effect of rutin and radiation on CAT in HT-29 cells $(24 \mathrm{~h})$.

\begin{tabular}{lc}
\hline Groups & $\begin{array}{c}\text { CAT }\left(\mu \text { moles of } \mathrm{H}_{2} \mathrm{O}_{2}\right. \\
\text { consumed } / \mathrm{min} / \mathrm{mg} \text { protein })\end{array}$ \\
\hline Sham control & $27.93 \pm 0.97^{\mathrm{a}}$ \\
Rutin $(80 \mu \mathrm{M})$ & $28.17 \pm 0.81^{\mathrm{a}}$ \\
4 Gy radiation & $21.34 \pm 0.95^{\mathrm{b}}$ \\
4 Gy radiation + Rutin $(80 \mu \mathrm{M})$ & $19.66 \pm 1.56^{\mathrm{c}}$ \\
\hline
\end{tabular}

Data are presented as means \pm SD of six sets of experiment in each group. Values not sharing a common superscript letter $\left.{ }^{(-\mathrm{a} e}\right)$ differ significantly at $\mathrm{p}<0.05$ (DMRT).

Tab. 4. Effect of rutin and radiation on GPx in HT-29 cells ( $24 \mathrm{~h})$.

\begin{tabular}{lc}
\hline Groups & $\begin{array}{c}\text { GPx }(\mu \text { moles of GSH } \\
\text { consumed/min/mg protein })\end{array}$ \\
\hline Sham control & $17.35 \pm 0.84^{\mathrm{a}}$ \\
Rutin $(80 \mu \mathrm{M})$ & $18.79 \pm 0.93^{\mathrm{a}}$ \\
4 Gy radiation & $15.99 \pm 1.56^{\mathrm{b}}$ \\
4 Gy radiation + Rutin $(80 \mu \mathrm{M})$ & $12.71 \pm 1.32^{\mathrm{c}}$ \\
\hline
\end{tabular}

Data are presented as means \pm SD of six sets of experiment in each group. Values not sharing a common superscript letter $\left.{ }^{(\mathrm{a}-\mathrm{e}}\right)$ differ significantly at $\mathrm{p}<0.05$ (DMRT).

revealed the cytotoxic effects (high $\mathrm{IC}_{50}$ concentration) of rutin treatment alone.

Mitochondria are responsible for a variety of key proceedings in the apoptotic process, such as changes in electron transport, generation of ROS and loss of mitochondrial transmembrane potential $(\Delta \Psi \mathrm{m})(30)$. ROS impairs mitochondrial ATP synthesis and $\mathrm{Ca}^{2+}$ homeostasis leading to mitochondrial dysfunction. Bhosle et al (31) have shown that the decrease in mitochondrial transmembrane potential is the cause of cell death or necrosis. In our study we observed that the combined effect of rutin and radiation treatment significantly decreased the mitochondrial transmembrane potential in HT-29 cells as compared to those in other treated groups. The loss in mitochondrial transmembrane potential can also be correlated with the enhanced apoptosis encountered on rutin and/or radiation treatment.

DNA damage plays a vital role in several human diseases including cancer (32). ROS generation in cancer cells may lead to DNA damage by the action of phytochemicals (33). Similarly, in our study, an increased DNA damage (comet assay) was noted on simultaneous treatment of HT-29 cells with rutin and X radiation as evidenced by the increased comet tail length and density. This could contribute to the increased rate of cell deaths in cancer cells and these effects may be due to the generation of ROS in HT-29 cells.

Lipid peroxidation and oxidative stress are known to play a vital role in numerous pathophysiological circumstances (34). Nowadays, a well-known and widely recognized approach is to study the consequences of free radicals by evaluating the oxidative damage to cellular membranes (35). Similarly, protein oxidation plays an important pathophysiological role and may affect protein function in normal and pathological processes. The most frequent precursor of protein oxidation indicator is the protein carbonyl content (PCC) (36). In our present work, we noticed increased concentrations of TBARS and PCC in HT-29 cells treated with rutin which reveals its prooxidant role.

Depending on the factors such as solubility, chelating property, $\mathrm{pH}$, and metal-reducing capacity, plant-derived antioxidant polyphenols act as both prooxidants and antioxidants. A number of polyphenols exhibit prooxidant activity under certain conditions such as higher doses, availability of metal ions (37), or due to the hypoxic environment (as in the case of cancer cells) (38). Damage to the biomolecules such as DNA, proteins and lipids in cancer cells could also be possibly due to the prooxidant properties of polyphenols (39). Although rutin is a naturally occurring antioxidant, at higher concentrations, rutin exhibits prooxidant activity, which might interrupt the mitochondrial dehydrogenase activity. This could explain the increased cytotoxicity of rutin at higher doses. These findings again correlate with previous reports which suggest that rutin possesses dual activities (26). In this context, Yamanaka et al (40) have also reported that the polyphenol caffeic acid exhibits prooxidant activity.

Moreover in our study HT-29 cells on the combined treatment with rutin and X-radiation showed markedly elevated concentrations of TBARS and PCC as compared to those on rutin-alone treatment. These findings suggest the radiosensitizing potential of rutin, which could be due to its ability to generate ROS. Thus, the ability of rutin to act as a prooxidant in the present experimental conditions could be a significant mechanism by which it induces cell death. In this context, Chendil et al (41) have also reported that plant-derived active principles show cytotoxic potential either alone or in combination with radiation at different circumstances.

In normal healthy cells, enzymatic and non-enzymatic antioxidants serve to balance the intracellular production of ROS, thereby delaying or inhibiting the oxidative destruction of molecular components within the cells. The activities of superoxide dismutase (SOD), catalase (CAT) and glutathione peroxidase (GPx) were markedly reduced when the cells were treated with rutin and exposed to 4 Gy radiation. The reduced activities of the enzymatic antioxidants (SOD, CAT, and GPx) would cause ROS accumulation resulting in oxidative stress. The increased generation of free radicals can in turn deplete the antioxidant levels in the cells. Thus, the reduced defence of tumour cells to irradiation could be due to the decreased levels of antioxidants (42). Together, these results suggest that treatment with rutin combined with radiation enhances cytotoxicity which could be attributed to its ability to act as a radiosensitizer.

To conclude, the treatment of HT-29 cells with rutin along with radiation exposure caused a pronounced chemoradiotherapeutic effect as confirmed by (i) the alterations in nuclear morphology, (ii) loss of mitochondrial transmembrane potential, (iii) marked induction of DNA damage, apoptosis, lipid peroxidation and (iv) reduction in enzymatic antioxidants. The above-mentioned effects confirm not only the anticancer property of rutin but also its ability to act as a radiosensitizer. These findings ultimately could be useful in devising new strategies to improve the therapeutic window in cancer treatment. 


\section{1-178}

\section{References}

1. Jemal A, Siegel R, Ward E. Cancer statistics. CA Cancer J Clin 2006; 56: $106-130$.

2. Kasibhatla S, Gourdeau H, Meerovitch K, Drewe J, Reddy S, Qiu L, Zhang H, Bergeron F, Bouffard D, Yang Q. Discovery and mechanism of action of a novel series of apoptosis inducers with potential vascular targeting activity. Mol Cancer Ther 2004; 3: 1365-1374.

3. Zhang SJ, Yu HQ, Wu LX. Degradation of calcium lignosulfonate using gamma-ray irradiation. Chemosphere 2004; 57: 1181-1187.

4. Jackson AL and Loeb LA. The contribution of endogenous sources of DNA damage to the multiple mutations in cancer. Mutat Res 2001; 477(1-2): 7-21.

5. Decker EA. Phenolics: prooxidants or antioxidants. Nutrition Rev 1997; 55(11): 396-398.

6. Marzouk MS, Soliman FM, Shehata IA, Rabee M, Fawzy GA. Flavonoids and biological activities of Jussiaearepens. Nat Prod Res 2007; 21: 436-443.

7. Chan Hun Jung, Cho Chul Hyung, Kim Chang Jong. Anti-asthmatic action of quercetin and rutin in conscious guinea-pigs challenged with aerosolized ovalbumin. Arch Pharmacol Res 2007; 30(12): 1599-1607.

8. Romero A, Paez A, Ferruelo M, Luja N, Berenguer A. Polyphenols in redwine inhibit the proliferation and induce apoptosis of $\mathrm{LNCaP}$ cells. BJU Int 2002; 89: 950-954.

9. ZiaeeA,Zamonsoltani, Nassiri-Ası M,Abassi E. Effects of rutin on lipid profile in hypercholesterolemic rats. Basic clin Pharmacol Toxicol 2009; 104: 253-254.

10. Janbaz A, Sheikh A, Saeedb AH. Protective effect of rutin on paracetamol and $\mathrm{CCl}_{4}$ induced hepatotoxicity in rodents. Fitoterapia 2002; 73: 557-563.

11. Pu F, Mishima K, Irie K, Motohashi K, Tanaka Y, Orito K, Egawa T, Kitamura Y, Egashira N, Iwasaki K, Fujiwara M. Neuroprotective effects of quercetin and rutin on spatial memory impairment in an 8-arm radial maze task and neuronal death induced by repeated cerebral ischemia in rats. J. Pharmacol Sci 2007; 104: 329-334.

12. La Casa C, Villegas I, Alarcon de la Lastra C, Motilva V, Martin Calero MJ. Evidence for protective and antioxidant properties of rutin, a natural flavone, against ethanol induced gastric lesions. J Ethnopharmacol 2000; 71: 45-53.

13. Seiwert TY, Salama JK, Vokes EE. The concurrent chemoradiation paradigm: General principles. Nat Clin Pract Oncol 2007; 4: 86-100.

14. Moding EJ, Kastan MB, Kirsch DG. Strategies for optimizing the response of cancer and normal tissues to radiation. Nat Rev Drug Discov 2013; 12: 526-542.

15. Xu Y. Induction of genetic instability by gain-of-function p53 cancer mutants. Oncogene 2008; 27: 3501-3507.

16. Mosmann T. Rapid colorimetric assay for cellular growth and survival: application to proliferation and cytotoxicity assays. Journal of Immunological Methods 1983; 65 (1-2): 55-63.

17. Chiu SJ, Hsaio CH, Tseng HH, Su YH, Shih WL, Lee JW, Chuah JQY. Rosiglitazone enhances the radiosensitivity of p53-mutant HT-29 human colorectal cancer cells. Biochemical and biophysical Research Communications 2010; 394: 774-779.

18. Spector DL, Goldman RD, Leinwand LA. Cells: A Laboratory Manual, Culture and Biochemical Analysis of Cells. New York: Cold Spring Harbor Laboratory Press, 1998.

19. Singh NP, McCoy MT, Tice RR, Schneider EL. A simple technique for quantitation of low levels of DNA damage in individual cells. Exp Cell Res 1988; 175(1): 184-191.

20. Niehaus WG and Samuelson B. Formation of malondialdehyde from phospholipids arachidonate during microsomal lipid peroxidation. Eur J Biochem 1968; 6: 126-130.

21. Levine RL, Wehr N, Williams JA, Stadtman ER, Shacter E. Determination of carbonyl groups in oxidized protein. Methods Mol Biol 2000; 99: 15-24.
22. Kakkar P, Das B, Viswanathan PN. A modified spectrophotometric assay of superoxide dismutase. Ind J Biochem Biophys 1984; 21: 130-132.

23. Sinha KA. Colorimetric assay of catalase. Anal Biochem 1972; 47: 389-394.

24. Rotruck JJ, Pope AL, Ganther HE, Swanson AB. Selenium: Biochemical rates as a component of glutathione peroxidase. Science 1973; 179: 588-590.

25. Fujisawa S, Atsumi T, Ishihara M, Kadoma Y. Cytotoxicity, ROS-generation activity and radical-scavenging activity and related compounds. Anticancer Res 2004; 24: 563-570.

26. Fukumoto LR and Mazza G. Assessing antioxidant and prooxidant activities of phenolic compounds. J Agr Food Chem 2000; 48(8): 3597-3604.

27. Ly J, Grubb D, Lawen A. The mitochondrial membrane potential ( $\triangle \Psi \mathrm{m})$ in apoptosis; an update. Apoptosis 2003; 8: 115-128.

28. Nair S, Li W, Kong A.N.T. Natural dietary anticancer chemopreventive compounds: redox-mediated differential signaling mechanisms in cytoprotection of normal cells versus cytotoxicity in tumor cells. Acta Pharmacol Sin 2007; 28 (4): 459-472.

29. Fukuoka K, Arioka H, Iwamoto Y, Fukumoto H, Kurokawa H, Ishida T, Tomonari A, Suzuki T, Usuda J, Kanzawa F, Saijo N, Nishio K. Mechanism of the radiosensitization induced by vinorelbine in human non-small cell lung cancer cells. Lung Cancer 2001; 34: 451-460.

30. Velho JA, Okanoboa H, Degasperi GR, Matsumato MY, Alberia LC, Cosso RG, Olieveira HCF, Vercesi AE. Statins induce calcium-dependent mitochondrial permeability transition. Toxicology 2006; 219: 124-132.

31. Bhosle SM, Huilgol NG, Mishra KP. Enhancement of radiation-induced oxidative stress and cytotoxicity in tumour cells by ellagic acid. Clin Acta 2005; 359: 89-100.

32. McKenna DJ, McKeown SR, McKelvey-Martin VJ. Potential use of the comet assay in the clinical management of cancer. Mutagenesis 2008; 23: $183-190$.

33. Srinivas P, Gopinath G, Banerji A, Dinakar A, Srinivas G. Plumbagin induces reactive oxygen species, which mediate apoptosis in human cervical cancer cells. Mol Carcinogen 2004; 40: 201-211.

34. Selvaraj N, Bobby Z, Sridhar MG. Oxidative stress: Does it play a role in the genesis of early glycated proteins. Med Hypo 2008; 70: 265-268.

35. Lykkesfeldt J, Svendsen. Oxidants and antioxidants in disease: Oxidative stress in farm animals. Vet J 2007; 173: 502-511.

36. Beal MF. Oxidatively modified proteins in aging and disease. Free Radic Biol Med 2002; 32 (9): 797-803.

37. Bouayed J, Bohn T. Exogenous antioxidants - Double-edged swords in cellular redox state. Health beneficial effects at physiologic doses versus deleterious effects at high doses. Oxid Med Cell Longevity 2010; 3 (4): 228-237.

38. Lee KW, Lee HJ. The roles of polyphenols in cancer chemoprevention. Biofactors 2006; 26 (2): 105-121.

39. Aruoma O. Methodological considerations for characterizing potential antioxidant actions of bioactive components in plant foods. Mutat Res 2003; 523-524: 9-20.

40. Yamanaka N, Oda O, Nagao S. Prooxidant activity of caffeic acid, dietary non-flavonoid phenolic acid, on $\mathrm{cu}^{2+}$ induced low density lipoprotein oxidation. FEBS let 1997; 405: 186-190.

41. Chendil D, Ranga RS, Meigooni D, Sathishkumar S, Ahmed MM. Curcumin confers radiosensitivity effect in prostate cancer cell line PC-3. Oncogene 2004; 23: 1599-1607.

42. Sergediene E, Jonsson K, Szymisiak H, Tyrakowsa B, Rietjens IM, Cenas N. Prooxidant toxicity of polyphenolic antioxidants to HL-60 cells description of quantitative structure activity relationships. FEBS Lett 1999; 462: 392-396. Accepted August 20, 2015. 